\title{
Light-curing units used in dentistry: factors associated with heat development — potential risk for patients
}

\author{
Mathieu Mouhat $^{1} \cdot$ James Mercer $^{2} \cdot$ Lina Stangvaltaite ${ }^{1} \cdot$ Ulf Örtengren $^{1,3}$
}

Received: 7 June 2016 / Accepted: 14 September 2016 / Published online: 1 October 2016

(C) The Author(s) 2016. This article is published with open access at Springerlink.com

\begin{abstract}
Objectives To investigate how heat development in the pulp chamber and coronal surface of natural teeth with and without cusps subjected to irradiance using light-emitting diode (LED)-light-curing units (LCUs) is associated with (i) irradiance, (ii) time, (iii) distance, and (iv) radiant exposure.

Materials and methods Three different LED-LCUs were used. Their irradiance was measured with a calibrated spectrometer (BlueLight Analytics Inc., Halifax, Canada). An experimental rig was constructed to control the thermal environment of the teeth. The LED-LCU tip position was accurately controlled by a gantry system. Tooth surface temperature was measured by thermography (ThermaCAM S65 HS, FLIR Systems, Wilsonville, USA) and pulp chamber temperature with a thermocouple. LED-LCU tip distance and irradiation times tested were 0,2 , and $4 \mathrm{~mm}$ and 10,20 , and $30 \mathrm{~s}$, respectively. Ethical permission was not required for the use of extracted teeth.

Results Maximum surface and pulp chamber temperatures were recorded in tooth without cusps $\left(58.1^{\circ} \mathrm{C} \pm 0.9^{\circ} \mathrm{C}\right.$ and $43.1{ }^{\circ} \mathrm{C} \pm 0.9{ }^{\circ} \mathrm{C}$, respectively). Radiant exposure explained the largest amount of variance in temperature, being more affected by time than irradiance.

Conclusions At all combinations of variables tested, repeated measurements produced consistent results indicating the
\end{abstract}

Ulf Örtengren

ulf.ortengren@uit.no

1 Department for Clinical Dentistry/Faculty of Health Sciences, The Arctic University of Norway (UIT), Tromsø, Norway

2 Department of Medical Biology/Faculty of Health Sciences, The Arctic University of Norway (UIT), Tromsø, Norway

3 Department of Cariology, Institute of Odontology/Sahlgrenska Academy, University of Gothenburg, Gothenburg, Sweden reliability of the method used. Increased exposure time seems to be the factor most likely to cause tissue damage.

Clinical relevance Risk of superficial tissue damage at irradiances $>1200 \mathrm{~mW} / \mathrm{cm}^{2}$ is evident. There is a risk of pulp damage when only thin dentin is left at higher irradiances $\left(>1200 \mathrm{~mW} / \mathrm{cm}^{2}\right)$. Clinicians should be aware of LED-LCU settings and possible high temperature generated.

Keywords Dentistry $\cdot$ Curing lights $\cdot$ Tooth $\cdot$ Light .

Temperature

\section{Introduction}

Polymer resin-based materials (e.g., adhesives, composites, and composite cements) are widely used in restorative dentistry. Photopolymerization dominates using blue light of a wavelength between 380 and $500 \mathrm{~nm}$ and with an irradiance of $>450 \mathrm{~mW} / \mathrm{cm}^{2}$. During the last 10 years, light-curing units (LCUs) employing light-emitting diode (LED) technology have largely taken over from the older quartz-tungstenhalogen (QTH) devices [1-3]. LED is considered as "cold light" created by recombination of electrons using crystals (e.g., GaN) releasing photons (i.e., light) when subjected to energy (i.e., voltage) [4]. The advantage of LED is a spectrum closer to the point for photoexcitation of the most widely used photoinitiators in dental resin-based composites (RBCs). In addition, use of energy is more efficient (i.e., more light and less heat) [3].

In recent years, light-curing unit employing light-emitting diode (LED-LCU) with higher energy output than previous generations of LCU have emerged on the market. The reason for this development trend is claimed to be shorter curing times and increased polymerization, although the latter is still a matter for discussion and has been questioned $[5,6]$. With 
higher output, there is a risk of increased temperature even with LED technology and concerns have been raised about increasing risk for pulp and tissue damage in patients $[1,2,7$, 8], a risk which also was of concern with QTH devices [9-11]. Hanning and Bott investigated QTH curing devices and showed a temperature increased of $\approx 8^{\circ} \mathrm{C}$ depending on energy output [11]. If the temperature of the pulpal tissue increases more than $5.5^{\circ} \mathrm{C}$, the tissue will start to coagulate, causing irreversible damage [12].

Although few investigations have been performed, especially with LED-LCU, an increase in energy output (irradiance) seemed to correlate best to increased temperature [5]. Complaints from patients in connection with light-curing procedures have been reported, including experience of "burning" sensations in teeth and in oral tissue [13].

Different brands of LED-LCU with the same expected output do not always produce the same amount of heat, and this may be due to differences between the light in spectral distribution [14], the type of LED-LCU tip (TIP) used and its diameter, and/or the use of a fan in the LEDLCU. In addition to the heat produced by the LED-LCU, the polymerization of the composite (i.e., exothermic reaction) has been discussed as causes for tissue damage (i.e., pulp damage) $[8,11,15,16]$. The light source is still, however, considered to be the main risk [17], even though the composite and the remaining dental hard tissue may give some protection [18].

There are major concerns from the authorities (e.g., EU) concerning risk of tissue damage in patients. Different methods have been used to shed more light on this problem. However, the results obtained vary with large discrepancy between different LED-LCUs [19-22]. The majority of the studies have looked into the matter of pulp damage, but there is also a risk for other tissue damage close to the TIP. By investigating the association of the irradiance with the temperature increase close to the TIP and in the pulp chamber using different types of LED-LCU at increased distances and curing times, more knowledge can be added for decreased risk for patients. While the temperature distribution on RBC has been investigated [23], to the best of our knowledge, there are no studies simultaneously measuring and combining the temperature distribution on the surface and in the pulp chamber in teeth subjected to LED-LCU.

The aim of this study was to develop a reliable bench model for investigating how heat development in the pulp chamber and coronal surface of natural teeth with and without cusps subjected to irradiance using three different LED-LCU is associated with (i) irradiance, (ii) time, (iii) distance, and (iv) radiant exposure (product of irradiance and time which represent the total light energy delivered to the $\mathrm{RBC}$ ).

\section{Materials and methods}

\section{LED-LCU tested}

Two different brands of LED-LCU were tested, Bluephase style ${ }^{\circledR}$ and Bluephase $\mathrm{G} 2 \AA$. One LED-LCU Bluephase G2® was tested in two modes (high mode and low mode). Two LED-LCU Bluephase style ${ }^{\circledR}$ were tested, one battery powered and one mains powered. These units are in everyday use in our university dental clinic, and complaints have been raised from patients suffering from pain caused by heat development during light curing.

\section{Irradiance measurement}

Two different brands of LED-LCU, Bluephase style $(n=10)$ and Bluephase $\mathrm{G} 2 \AA(n=10)$, from the same manufacturer (IvoClar/Vivadent, Schaan, Lichtenstein) were tested for irradiance using a calibrated laboratory-grade NIST-referenced USB4000 spectrometer (Managing Accurate Resin Curing (MARC) System; Bluelight Analytics Inc., Halifax, Canada). The objective was to evaluate eventual differences in irradiance among the curing unit within the same brand. The LED-LCU were battery powered, the batteries being fully charged on all test occasions. The working capacity of the LED-LCU lithium-polymer battery for the two brands of LED-LCU is $\approx 60 \mathrm{~min}$. Bluephase $\mathrm{G} 2{ }^{\circledR}$ was tested in high mode. One Bluephase style ${ }^{\circledR}$ was also tested when connected to main electricity. Caution was taken in the precise placement of the TIP on the sensor of the measurement equipment. To achieve this, we used an adjustable precision gantry with a 0.1-mm scale (\#55025, Edmunds Optics, Barrington, NJ). For evaluation of differences among units in the same brand, five measurements for each unit at 0 -mm distance were conducted at irradiation times of 10,20 , and $30 \mathrm{~s}$, respectively. The variation in irradiance was small for 9 out of 10 units in the same brand. One of these 9 units for each brand was randomly selected for the temperature profile experiments.

\section{Preparation of teeth}

For the temperature profile experiments, caries-free human third molars were used. The teeth were extracted for surgical reasons and not older than 6 months. They were stored in $0.5 \%$ chloramine-T solution according to ISO/TS 11405 2015 in a refrigerator $\left(4 \pm 1{ }^{\circ} \mathrm{C}\right)$ prior to use. In one tooth (T1), a class I cavity was prepared with a cylindrical diamond $(\varnothing=1.2 \mathrm{~mm})$ bur through the enamel and into the dentin. The apex of the root was cut and the channel prepared up to the pulp chamber with K-files (Densply/Maillefer, Ballaigues, Switzerland) 35 and 70 . The tip of a thin $(0.2 \mathrm{~mm})$ type T (copper constantan) thermocouple was inserted into the pulp chamber via the prepared channel, and its position was 
controlled with radiography (Planmeca Intra X-ray unit with Romexis, Planmeca Oy, Helsinki, Finland). The remaining pulpal wall had a thickness of $1.3 \pm 0.2 \mathrm{~mm}$ as assessed from the radiograph. In order to avoid an air space surrounding the tip of thermocouple inside the pulp chamber, the prepared channel was filled with glycerol prior to insertion of the thermocouple. The excess glycerol (spillage) during insertion was removed. Glass Ionomer (Fuji I®, GC Corp., Tokyo, Japan) was used to seal the apex and secure the thermocouple.

Due to the unevenness of the occlusal surface, the distance from the TIP to the pulpal wall is quite large. Under certain clinical conditions, for example, a tooth with removed cusps, the TIP will come closer to the pulpal wall. This situation was also taken into account in the experimental design and involved a slightly different preparation of the tooth under investigation. A second tooth (T2) was cut in the horizontal plane using a diamond saw (Accutom 50, Struers, Ballerup, Denmark), creating a flat dentin surface with a pulpal wall thickness of approximately $0.6 \mathrm{~mm}$. Radiography was also used to control placement of the thermocouple and thickness of the dentin wall as described above.

\section{Controlling the baseline thermal environment}

In an attempt to simulate as closely as possible the thermal conditions within the oral cavity, a special experimental rig was constructed (Fig. 1), involving the use of a thermostatically controlled circulating water bath (AH15L HT, VWR International, Radnor, USA) maintained at $37 \pm 1{ }^{\circ} \mathrm{C}$. The individual tooth under investigation was inserted approximately halfway (at the cemento-enamel junction) through an opening in the centre of a $75 \times 50 \times 1.25$-mm-thick plastic sheet, in such a way that the root was visible on one side and the crown on the other. The edges of the plastic plate were in turn glued to one side of a 12-mm-thick sheet of expanded polystyrene that had a rectangular-shaped opening with slightly smaller dimensions to the plastic plate. The plastic plate was attached to the polystyrene plate with the coronal side of the tooth situated within the open space of the polystyrene plate. This combined unit was then positioned on the water surface inside the thermostatically controlled circulating water bath, such that the root was immersed below the water surface and the coronal part in the air (Fig. 1b). A second thermocouple was placed in the air space $\approx 2 \mathrm{~mm}$ from the coronal side of the tooth for measuring the air temperature in the immediate vicinity of the tooth. The thermocouples used were calibrated prior to the experiment against a certified reference thermometer than had been calibrated against a traceable reference source (Norwegian Standards Organization). The temperature accuracy was $0.1{ }^{\circ} \mathrm{C}$.

The surface temperature of the tooth was measured by thermography using a high-precision infrared camera (ThermaCAM S65 HS, FLIR Systems, Wilsonville, USA) with a close-up lens
(LW64/150). This camera can produce high-definition digital IR images with an accuracy of $0.1^{\circ} \mathrm{C}$. The thermographic temperature data were recorded at 1-s intervals and stored for later analysis. The thermal emissivity was set at 0.98 . The thermographic images (thermograms) were processed using ThermaCAM Researcher Pro 2.8 SR-2 (FLIR Systems, Wilsonville, USA). The infrared camera was regularly calibrated against a black body with a traceable temperature source (model IR-2103/301, Infrared Systems Development Corporation, FL, USA). Although the absolute accuracy of this infrared camera is $30 \mathrm{mK}$, the processed temperature data was rounded off to $0.1{ }^{\circ} \mathrm{C}$.

For temperature measurements, the LED-LCU chosen from the irradiance test (Bluephase style $₫$ \#1100015231, Bluephase G2® \#P626170S591130, and Bluephase style $®$ electrically powered unit \#1100008001) were tested at the following combinations of curing time and distance from the tooth surface $(10,20$, and $30 \mathrm{~s}$ and 0,2 , and $4 \mathrm{~mm}$, respectively). The curing times chosen are within the range recommended by the manufacturers. The chosen distances of the TIP from the tooth were based on those generally used in a clinical setting. For Bluephase $\mathrm{G} 2 \AA$, the tests were performed both in low $\left(\approx 700 \mathrm{~mW} / \mathrm{cm}^{2}\right)$ and high modes $(\approx 1400 \mathrm{~mW} /$ $\mathrm{cm}^{2}$ ). Five repeated measurements for each distance/time combination were performed. All temperature data were continuously recorded before, during, and after a simulated curing cycle. Between each measurement, a recovery time was allowed to make sure that the temperatures had returned to its baseline value (pre-irradiation value).

\section{Ethical permission}

Since the experiments involved the use of human material (i.e., extracted teeth), ethical permission was asked for from the Norwegian Regional Committee for Medical and Health Research Ethics (REK). The committee concluded that such permission was not required (2015/234/REK Nord).

\section{Statistics}

In the analysis of the experimental data, the null hypothesis formulated was that the heat development is not associated with (i) irradiance, (ii) time, and (iii) distance. Statistical analyses were carried out using Statistical Package for the Social Sciences (SPSS, version 22.0, IBM, Somers, NY, USA). Statistical evaluation was performed using Wilcoxon rank sum test for comparisons between means of irradiance. Eight multiple linear regression models were constructed to evaluate heat development on the surface and the pulp chamber (dependent variables) on $\mathrm{T} 1$ and $\mathrm{T} 2$. In addition, 16 multiple regression models were constructed in order to compare the 
Fig. 1 a, b The placement of a tooth in the thin plastic sheet with the root visible on one side and the crown on the other are shown. During an experiment, the thin plastic sheet with the mounted tooth was placed on the water surface, such that the root was submerged in the water. $\mathbf{c}$ The position of the LED-LCU being tested. Overview of the experimental setup (d) showing the position of the infrared camera over the opening of the water bath during an experiment

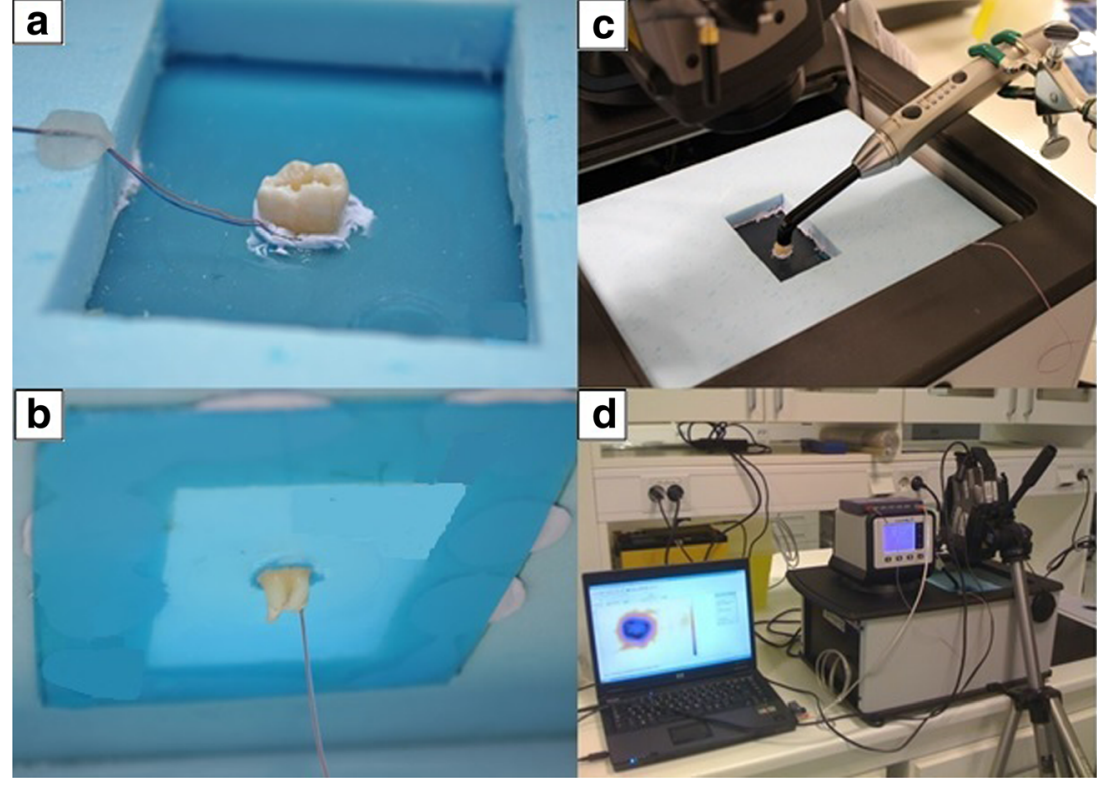

influence on temperature of different LED-LCU and curing modes (Bluephase style $®$ electrically powered, Bluephase style ${ }^{\circledR}$ battery, Bluephase G2® high mode, and Bluephase G2® low mode) on T2. The first type of models (model 1) included irradiance, time, and distance as independent variables, while the other type models (model 2 ) included radiant exposure (product of irradiance and time) and distance. Forced entry method was used. $R^{2}$ was recorded for the whole model and for each variable in order to evaluate their impact on the variation in the temperature. The level of significance was set to $5 \%$ and confidence interval to $95 \%$.

\section{Results}

\section{Irradiance measurement}

The mean values of irradiance of ten Bluephase style ${ }^{\circledR}$ LEDLCU and mean value of ten Bluephase G2® LED-LCU were statistically significantly different (Table 1). There was also a significant difference in irradiance with time within the ten Bluephase style ${ }^{\circledR}$ units (Table 1).
The irradiance was higher than claimed from the manufacturer for the majority of the units tested (Table 1). For Bluephase style ${ }^{\circ}$, the claimed maximum irradiance was $1100 \pm 10 \% \mathrm{~mW} / \mathrm{cm}^{2}$ and for Bluephase $\mathrm{G} 2 \AA$ $1200 \pm 10 \% \mathrm{~mW} / \mathrm{cm}^{2}$.

\section{Temperature measurement}

The temperature distribution on the surface of the T1 was nonuniform compared to T2 (Fig. 2a, b). The increase in pulp chamber temperature was less for T1 compared to T2 (Tables 2 and 3). The maximal surface temperature was $58.1 \pm 0.9{ }^{\circ} \mathrm{C}$ (for $\mathrm{T} 2$ at 2-mm distance, 30-s curing time), and the maximal pulp chamber temperature was $43.1 \pm 0.9^{\circ} \mathrm{C}$ (for T2 at $0 \mathrm{~mm}, 30$-s curing time) (Tables 5 and 7).

Multiple linear regression analyses (model 1) showed that time explained most of the variation in the pulp chamber $\left(R^{2}=0.69\right)$ and surface $\left(R^{2}=0.47\right)$ temperature in T1 as well as of pulp chamber temperature in T2 $\left(R^{2}=0.38\right)$ (Table 8$)$.

For T1, increasing the irradiation time from 10 to $20 \mathrm{~s}$ caused an increase of surface temperature of $4.2{ }^{\circ} \mathrm{C}$ $(p<0.001)$ (Table 8). Extending the irradiation time to
Table 1 Mean (SD) for the irradiance of the two different light-curing units tested, Bluephase style ${ }^{\circledR}$ battery $(n=10)$ and Bluephase G2@ high mode $(n=10)$, at three different curing times

\begin{tabular}{|c|c|c|}
\hline $\begin{array}{l}\text { Curing } \\
\text { time }\end{array}$ & $\begin{array}{l}\text { Irradiance of Bluephase style }{ }^{\circledR} \text { battery in } \\
\mathrm{mW} / \mathrm{cm}^{2}\end{array}$ & $\begin{array}{l}\text { Irradiance of Bluephase } \mathrm{G} 2{ }^{\circledR} \text { high mode in } \\
\mathrm{mW} / \mathrm{cm}^{2}\end{array}$ \\
\hline $10 \mathrm{~s}$ & 1337 (104) ade & 1411 (142) a \\
\hline $20 \mathrm{~s}$ & 1477 (240) bd & $1362(121) b$ \\
\hline $30 \mathrm{~s}$ & $1479(96)$ ce & $1382(102) \mathrm{c}$ \\
\hline
\end{tabular}

The letters a-c indicate significant difference $(p<0.05)$ between Bluephase G2® and Bluephase style@ at the different times tested respectively. The letter d-e indicates significant difference $(p<0.05)$ in irradiance at different times for Bluephase style ${ }^{\circ}$. Wavelength for the two light-curing units was $385-515 \mathrm{~nm}$ 
Fig. 2 Thermograms showing temperature distribution on the surface of a tooth when subjected to a 30-s irradiation with a LED light-curing unit Bluephase style ${ }^{\circledR}$. a Thermogram of tooth with a flat dentin surface with a pulpal wall thickness of approximately $0.6 \mathrm{~mm}$ (T2). b Thermogram of tooth with class I cavity (T1)

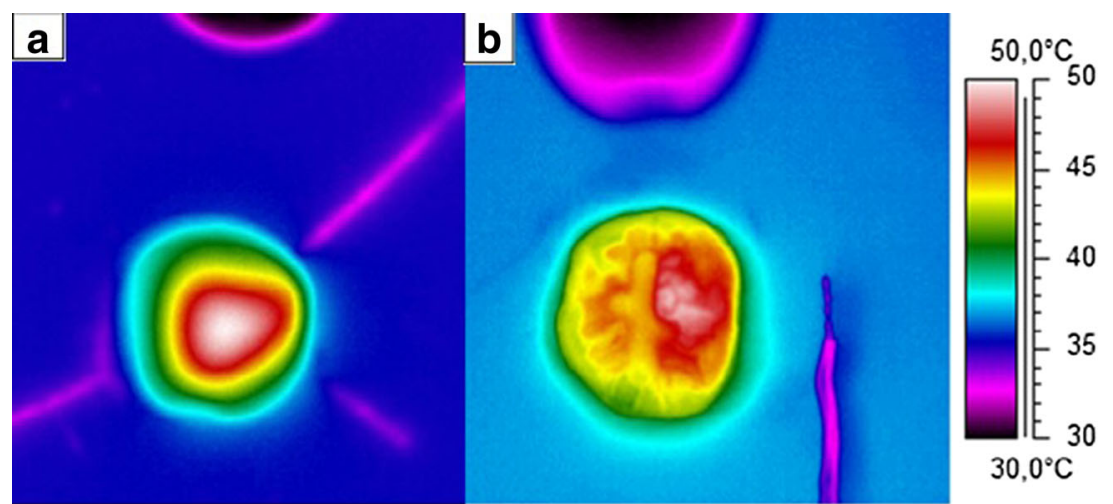

$30 \mathrm{~s}$ caused the surface temperature to increase by $7.3{ }^{\circ} \mathrm{C}$ $(p<0.001)$ (Table 8$)$. There was a statistically significant increase in the surface temperature $\left(0.8^{\circ} \mathrm{C}\right)$ when increasing irradiation by $100 \mathrm{u}\left(\mathrm{mW} / \mathrm{cm}^{2}\right)(p<0.001)$ (Table 8$)$. In all experiments, in $\mathrm{T} 1$ pulp, chamber temperature was never greater than $37.9{ }^{\circ} \mathrm{C}$ (Table 2).

For T2, extending the curing time from 10 to $20 \mathrm{~s}$ caused the pulp chamber temperature to increase by $1.6{ }^{\circ} \mathrm{C}(p<0.001)$, while extending curing time to $30 \mathrm{~s}$, pulp chamber temperature increased by $2.6^{\circ} \mathrm{C}(p<0.001)$ (Table 8).

For T2, the temperature increase on the surface was more explained by irradiance than time $\left(R^{2}=0.41\right.$ and $R^{2}=0.18$, respectively, in multiple linear regression analysis model 1). There was a statistically significant increase in the surface temperature $\left(1.3^{\circ} \mathrm{C}\right)$ when increasing irradiation by $100 \mathrm{u}\left(\mathrm{mW} / \mathrm{cm}^{2}\right)(p<0.001)$ (Table 8$)$.

For both T1 and T2, radiant exposure was shown to be the most important factor for heat development according to multiple regression analysis model 2 . For T1, $69 \%$ of the variation of the surface temperature and $75 \%$ of the pulp chamber temperature were explained by radiant exposure. For T2, the outcomes were $47 \%$ (surface temperature) and $62.5 \%$ (pulp temperature), respectively (Table 8). Since radiant exposure is calculated as a function of watt $\times$ time/ area, time will still be the most important factor on the temperature variation.

When the different LED-LCU and curing modes were compared (Bluephase style ${ }^{\circledR}$ electrically powered, Bluephase style ${ }^{\circledR}$ battery, Bluephase G2® high mode, and Bluephase $G 2 ®$ low mode), multiple linear regression analyses similarly showed that time was the most important factor for the temperature variations on T2 (data not shown). Independent variables in these analyses were time and distance, as irradiance had to be removed from the model due to multicollinearity. There was one exception (Bluephase style $\AA$ battery), where pulp chamber temperature was equally explained by time $\left(R^{2}=0.46\right)$ and distance $\left(R^{2}=0.47\right)$. An increase of the irradiation time caused a pulp chamber temperature increase of $2.5^{\circ} \mathrm{C}(p<0.001)$, while increasing the distance from 0 to $4 \mathrm{~mm}$ caused a pulp chamber temperature decrease of $2.5^{\circ} \mathrm{C}(p<0.001)$.
Table 2 Temperature variations at the surface and in the pulp chamber at different radiant exposure (product of irradiance and time (s)). Distance from the surface (top of the cusp from tooth with class I cavity (T1)) light-curing unit tip $0 \mathrm{~mm}$. The table shows the results for $\mathrm{T} 1$

\begin{tabular}{lrlll}
\hline $\begin{array}{l}\text { Light-curing unit } \\
\left(\text { irradiance }-\mathrm{mW} / \mathrm{cm}^{2}\right)\end{array}$ & $\begin{array}{l}\text { Radiant exposure } \\
\left(\mathrm{J} / \mathrm{cm}^{2}\right)\end{array}$ & $\begin{array}{l}\text { Surface } \\
\text { temperature }\left({ }^{\circ} \mathrm{C}\right)\end{array}$ & $\begin{array}{l}\text { Pulp chamber } \\
\text { temperature }\left({ }^{\circ} \mathrm{C}\right)\end{array}$ & $\begin{array}{l}\text { Time } \\
(\mathrm{s})\end{array}$ \\
\hline $\begin{array}{c}\text { Bluephase style plugged } \\
(1184 \pm 12)\end{array}$ & $35.9 \pm 0.4$ & $49.3 \pm 0.4$ & $37.6 \pm 0.1$ & 30 \\
& $23.9 \pm 0.3$ & $45.6 \pm 0.1$ & $37.2 \pm 0$ & 20 \\
Bluephase G2 high mode & $44.1 \pm 1.9$ & $41.2 \pm 0.2$ & $36.9 \pm 0$ & 10 \\
$(1471 \pm 65)$ & $29.4 \pm 1.3$ & $48.2 \pm 0.4$ & $37.9 \pm 0.1$ & 30 \\
& $14.6 \pm 0.8$ & $43.7 \pm 0.3$ & $37.1 \pm 0.1$ & 20 \\
Bluephase G2 low mode & $23.0 \pm 1.4$ & $45.7 \pm 0.2$ & $37.3 \pm 0$ & 10 \\
$(767 \pm 46)$ & $15.3 \pm 0.9$ & $42.8 \pm 0.6$ & $37.1 \pm 0.1$ & 30 \\
& $7.7 \pm 0.5$ & $39.6 \pm 0.3$ & $36.9 \pm 0$ & 20 \\
Bluephase style battery & $38.1 \pm 0.6$ & $49.5 \pm 0.3$ & $37.6 \pm 0.1$ & 10 \\
$(1268 \pm 21)$ & $25.4 \pm 0.4$ & $46.3 \pm 0.3$ & $37.3 \pm 0$ & 30 \\
& $12.7 \pm 0.2$ & $43.1 \pm 0.4$ & $37.1 \pm 0$ & 20 \\
& & & 10 \\
\hline
\end{tabular}


Table 3 Temperature variations at the surface and in the pulp chamber at different radiant exposure (product of irradiance and time (s)). The table shows the results for the tooth with a flat dentin surface with a pulpal wall thickness of approximately $0.6 \mathrm{~mm}$ (T2). Distance from the surface to the light curing unit tip $0 \mathrm{~mm}$

\begin{tabular}{lllll}
\hline $\begin{array}{l}\text { Light-curing unit } \\
\left.\text { (irradiance- } \mathrm{mW} / \mathrm{cm}^{2}\right)\end{array}$ & $\begin{array}{l}\text { Radiant exposure } \\
\left(\mathrm{J} / \mathrm{cm}^{2}\right)\end{array}$ & $\begin{array}{l}\text { Surface } \\
\text { temperature }\left({ }^{\circ} \mathrm{C}\right)\end{array}$ & $\begin{array}{l}\text { Pulp chamber } \\
\text { temperature }\left({ }^{\circ} \mathrm{C}\right)\end{array}$ & $\begin{array}{l}\text { Time } \\
(\mathrm{s})\end{array}$ \\
\hline $\begin{array}{c}\text { Bluephase style plugged } \\
(1257 \pm 4)\end{array}$ & $37.8 \pm 0.1$ & $44.4 \pm 0.8$ & $40.8 \pm 0.2$ & 30 \\
& $25.1 \pm 0.1$ & $42.5 \pm 0.4$ & $39.2 \pm 0.1$ & 20 \\
Bluephase G2 high mode & $12.6 \pm 0.1$ & $40.1 \pm 0.3$ & $38.4 \pm 0.1$ & 10 \\
$(1437 \pm 14)$ & $28.1 \pm 0.4$ & $46.9 \pm 1.2$ & $43.1 \pm 0.9$ & 30 \\
& $14.6 \pm 0.1$ & $45.3 \pm 1.2$ & $41.4 \pm 0.3$ & 20 \\
Bluephase G2 low mode & $23.2 \pm 0.2$ & $41.5 \pm 0.3$ & $39.1 \pm 0.2$ & 10 \\
$(774 \pm 7)$ & $15.5 \pm 0.1$ & $40.3 \pm 0.3$ & $38.1 \pm 0.2$ & 30 \\
& $7.7 \pm 0.1$ & $38.1 \pm 0.2$ & $37.2 \pm 0.1$ & 20 \\
Bluephase style battery & $36.7 \pm 0.3$ & $52.6 \pm 0.5$ & $42.5 \pm 0.4$ & 10 \\
$(1222 \pm 9)$ & $24.4 \pm 0.2$ & $52.5 \pm 0.4$ & $41.5 \pm 0.3$ & 30 \\
& $12.2 \pm 0.1$ & $48.6 \pm 0.7$ & $40.0 \pm 0.1$ & 20 \\
\hline
\end{tabular}

An increase in surface temperature with increasing distance from 0 to $2 \mathrm{~mm}$ was seen for all LED-LCU (Tables 4, 5, 6, and $7)$. For the Bluephase G2®, this was also seen when the distance was increased to $4 \mathrm{~mm}$ irrespective of the mode used. Even though the irradiance (and radiant exposure accordingly) was lower at 2-mm distance for the Bluephase G2® high mode, the surface temperature increased $\left(52.2 \pm 0.6{ }^{\circ} \mathrm{C}\right.$ at $2 \mathrm{~mm}$ vs. $46.9 \pm 1.2{ }^{\circ} \mathrm{C}$ at $0 \mathrm{~mm}$ ) when irradiated for $30 \mathrm{~s}$ (Table 5). For the same unit in low mode and for the Bluephase style ${ }^{\circledR}$ battery tested, the recorded increase in surface temperature followed the increase in irradiance (and radiant exposure accordingly) at different distances (Tables 6 and 7).

\section{Discussion}

In this study, heat development on the surface and in the pulp chamber in extracted teeth subjected to irradiation with different LED-LCU has been investigated. In such a study, accurate temperature measurements as well as accurate control over the baseline thermal environment of the teeth under investigation is of the utmost importance. Great care was taken to ensure that these conditions were achieved. By being able to accurately control the baseline pulp temperature as well as the air temperature surrounding the crown of the tooth using a thermostatically controlled water bath system, we were able to mimic the thermal conditions within the oral cavity (Fig. 2). With regards to the pulp chamber and tooth coronal surface temperature measurements, great care was taken to ensure that the thermocouples and the high-precision infrared camera used for measuring the temperature responses in the pulp chamber and on the surface of the teeth, respectively, were accurately calibrated. The accurate and stable placement of the teeth in the water bath produced results with low standard deviation, and good repeatability at each of the test situations lend further support concerning the reliability of the method used. However, the experimental setup has some limitations in that it can never completely reflect a true clinical situation. Not least, the pulp chamber in the experimental teeth lacks blood
Table 4 Irradiance, radiant exposure (product of irradiance and time (s)), and heat development (surface temperature and pulp chamber temperature) at different distances (on tooth with a flat dentin surface with a pulpal wall thickness of approximately $0.6 \mathrm{~mm}$ (T2)) with different lightcuring units, Bluephase style $®$ plugged

\begin{tabular}{llllll}
\hline $\begin{array}{l}\text { Distance } \\
(\mathrm{mm})\end{array}$ & $\begin{array}{l}\text { Irradiance } \\
\left(\mathrm{mW} / \mathrm{mm}^{2}\right)\end{array}$ & $\begin{array}{l}\text { Time } \\
(\mathrm{s})\end{array}$ & $\begin{array}{l}\text { Radiant exposure } \\
\left(\mathrm{J} / \mathrm{mm}^{2}\right)\end{array}$ & $\begin{array}{l}\text { Surface } \\
\text { temperature }\left({ }^{\circ} \mathrm{C}\right)\end{array}$ & $\begin{array}{l}\text { Pulp chamber } \\
\text { temperature }\left({ }^{\circ} \mathrm{C}\right)\end{array}$ \\
\hline 0 & $1257 \pm 4$ & 30 & $37.8 \pm 0.1$ & $44.4 \pm 0.8$ & $40.8 \pm 0.2$ \\
& & 20 & $25.1 \pm 0.1$ & $42.5 \pm 0.4$ & $39.2 \pm 0.1$ \\
2 & 10 & $12.6 \pm 0.1$ & $40.1 \pm 0.3$ & $38.4 \pm 0.1$ \\
& $1250 \pm 9$ & 30 & $37.5 \pm 0.3$ & $44.9 \pm 0.4$ & $40.5 \pm 0.4$ \\
& & 20 & $25.0 \pm 0.2$ & $42.9 \pm 0.3$ & $39.6 \pm 0.2$ \\
& 10 & $12.5 \pm 0.1$ & $40.3 \pm 0.2$ & $37.9 \pm 0.2$ \\
& $1176 \pm 6$ & 30 & $35.3 \pm 0.2$ & $42.8 \pm 0.3$ & $39.4 \pm 0.3$ \\
& & 20 & $23.5 \pm 0.1$ & $41.1 \pm 0.4$ & $38.3 \pm 0.2$ \\
& & 10 & $11.8 \pm 0.1$ & $38.9 \pm 0.4$ & $37.2 \pm 0.1$ \\
\hline
\end{tabular}


Table 5 Irradiance, radiant exposure (product of irradiance and time (s)) and heat development (surface temperature and pulp chamber temperature) at different distances (on tooth with a flat dentin surface with a pulpal wall thickness of approximately $0.6 \mathrm{~mm}$ (T2)) with different lightcuring units, Bluephase $\mathrm{G} 2{ }^{\circledR}$ high mode

\begin{tabular}{llllll}
\hline $\begin{array}{l}\text { Distance } \\
(\mathrm{mm})\end{array}$ & $\begin{array}{l}\text { Irradiance } \\
\left(\mathrm{mW} / \mathrm{mm}^{2}\right)\end{array}$ & $\begin{array}{l}\text { Time } \\
(\mathrm{s})\end{array}$ & $\begin{array}{l}\text { Radiant exposure } \\
\left(\mathrm{J} / \mathrm{mm}^{2}\right)\end{array}$ & $\begin{array}{l}\text { Surface } \\
\text { temperature }\left({ }^{\circ} \mathrm{C}\right)\end{array}$ & $\begin{array}{l}\text { Pulp chamber } \\
\text { temperature }\left({ }^{\circ} \mathrm{C}\right)\end{array}$ \\
\hline 0 & $1437 \pm 14$ & 30 & $43.1 \pm 0.4$ & $46.9 \pm 1.2$ & $43.1 \pm 0.9$ \\
& & 20 & $28.7 \pm 0.3$ & $45.3 \pm 1.2$ & $41.4 \pm 0.3$ \\
& 10 & $14.6 \pm 0.1$ & $42.5 \pm 0.3$ & $39.1 \pm 0.2$ \\
& $1412 \pm 16$ & 30 & $42.4 \pm 0.5$ & $52.2 \pm 0.6$ & $42.7 \pm 0.6$ \\
& & 20 & $28.3 \pm 0.3$ & $49.1 \pm 0.2$ & $41.9 \pm 0.3$ \\
& $1513 \pm 16$ & 30 & $45.4 \pm 0.5$ & $48.7 \pm 0.5$ & $40.7 \pm 0.8$ \\
& & 20 & $30.3 \pm 0.3$ & $46.2 \pm 1.1$ & $39.3 \pm 0.3$ \\
& & 10 & $15.1 \pm 0.2$ & $42.8 \pm 0.3$ & $37.6 \pm 0.1$ \\
\hline
\end{tabular}

perfusion, which might affect heat exchange from the tooth. In addition, while our laboratory setup allowed for exact and stable placement of the TIP during a light-curing cycle, it is unlikely that this would occur in a clinical situation [24]. Further, a laboratory bench model can never simulate the environmental conditions within the oral cavity. An additional consideration that has to be taken into account when comparing temperature distribution from different LED-LCUs relates to differences in the homogeneity of irradiance from the different TIPs $[25,26]$. Price at al. evaluated TIPs and found regions in some TIP area that delivered less than $400 \mathrm{~mW} /$ $\mathrm{cm}^{2}$, while others delivered more than $4500 \mathrm{~mW} / \mathrm{cm}^{2}$ [23]. It is assumed that it was probably due to differences in TIP design. Due to the focusing properties of the TIPs, irradiance will be affected with increased distance from the surface [27-29]. The observed paradoxical temperature increase for T2 with increased distance for some LED-LCUs might be due to TIP design affecting the irradiance (Tables 4-7). The observed changes in pulp chamber temperatures did not reflect this issue as did the surface temperature. LED-LCU irradiance tested in the present study was higher than stated by the manufacturer. The matter of discrepancy between the output stated by a manufacturer's and the actual values measured by researchers has been addressed [23].
Irrespective of the type of the LED-LCU used, surface and pulp chamber temperature increased with curing time and irradiance, with increased curing time being clearly the dominant parameter (Table 8). An adequate curing time is necessary in order to obtain an accurate degree of conversion of the RBC [30]. Even modern RBCs are based on methacrylates that require sufficient irradiance and time for proper curing. With inadequate curing time, there is a risk of less cohesion in the network due to less cross-linking and secondary forces. Increasing the irradiance will only, to a limited degree, compensate for a shortened irradiation time [31, 32]. Price et al. (2014) concluded that for RBC, it could be beneficial to increase the curing time of LED-LCU beyond the manufacturer's recommendations. [33]. However, increased curing time leads to higher temperature and the negative consequence of high temperature during light curing has been a focal point concerning potential pulpal tissue damage [2, 19-21, 24, 34, 35]. This is especially relevant in relation to worn teeth or teeth with larger destructions having a limited amount of dental tissue. In such a situation, light curing is more likely to cause thermally related pulpal tissue damage [36]. The findings of the present study (Tables 2-8) support the latter. For example, the maximal temperature in the pulp chamber in T2 was $43.1 \pm 0.9{ }^{\circ} \mathrm{C}$. In cases of thin dentinal walls, close
Table 6 Irradiance, radiant exposure (product of irradiance and time (s)), and heat development (surface temperature and pulp chamber temperature) at different distances (on tooth with a flat dentin surface with a pulpal wall thickness of approximately $0.6 \mathrm{~mm}$ (T2)) with different lightcuring units, Bluephase G2® low mode

\begin{tabular}{llllll}
\hline $\begin{array}{l}\text { Distance } \\
(\mathrm{mm})\end{array}$ & $\begin{array}{l}\text { Irradiance } \\
\left(\mathrm{mW} / \mathrm{mm}^{2}\right)\end{array}$ & $\begin{array}{l}\text { Time } \\
(\mathrm{s})\end{array}$ & $\begin{array}{l}\text { Radiant exposure } \\
\left(\mathrm{J} / \mathrm{mm}^{2}\right)\end{array}$ & $\begin{array}{l}\text { Surface } \\
\text { temperature }\left({ }^{\circ} \mathrm{C}\right)\end{array}$ & $\begin{array}{l}\text { Pulp chamber } \\
\text { temperature }\left({ }^{\circ} \mathrm{C}\right)\end{array}$ \\
\hline 0 & $774 \pm 7$ & 30 & $23.2 \pm 0.2$ & $41.5 \pm 0.3$ & $39.1 \pm 0.2$ \\
& 20 & $15.5 \pm 0.1$ & $40.3 \pm 0.3$ & $38.5 \pm 0.2$ \\
& & 10 & $7.7 \pm 0.1$ & $38.1 \pm 0.2$ & $37.2 \pm 0.1$ \\
& & 30 & $24.8 \pm 0.2$ & $41.1 \pm 0.7$ & $39.2 \pm 0.3$ \\
& & 20 & $16.5 \pm 0.1$ & $40.5 \pm 0.2$ & $38.2 \pm 0.2$ \\
& & 10 & $8.3 \pm 0.1$ & $38.2 \pm 0.3$ & $37.1 \pm 0.2$ \\
& & 30 & $25.9 \pm 0.2$ & $42.2 \pm 0.3$ & $38.5 \pm 0.3$ \\
& & 20 & $17.3 \pm 0.1$ & $40.8 \pm 0.3$ & $37.6 \pm 0.2$ \\
& & 10 & $8.6 \pm 0.1$ & $38.7 \pm 0.3$ & $36.9 \pm 0.1$ \\
\hline
\end{tabular}


Table 7 Irradiance, radiant exposure (product of irradiance and time (s)), and heat development (surface temperature and pulp chamber temperature) at different distances (on tooth with a flat dentin surface with a pulpal wall thickness of approximately $0.6 \mathrm{~mm}$ (T2)) with different lightcuring units, Bluephase style ${ }^{\circledR}$ battery

\begin{tabular}{llllll}
\hline $\begin{array}{l}\text { Distance } \\
(\mathrm{mm})\end{array}$ & $\begin{array}{l}\text { Irradiance } \\
\left(\mathrm{mW} / \mathrm{mm}^{2}\right)\end{array}$ & $\begin{array}{l}\text { Time } \\
(\mathrm{s})\end{array}$ & $\begin{array}{l}\text { Radiant exposure } \\
\left(\mathrm{J} / \mathrm{mm}^{2}\right)\end{array}$ & $\begin{array}{l}\text { Surface } \\
\text { temperature }\left({ }^{\circ} \mathrm{C}\right)\end{array}$ & $\begin{array}{l}\text { Pulp chamber } \\
\text { temperature }\left({ }^{\circ} \mathrm{C}\right)\end{array}$ \\
\hline $0 \mathrm{~mm}$ & $1222 \pm 9$ & 30 & $36.7 \pm 0.3$ & $52.6 \pm 0.5$ & $42.5 \pm 0.4$ \\
& & 20 & $24.4 \pm 0.2$ & $52.5 \pm 0.4$ & $41.5 \pm 0.3$ \\
& & 10 & $12.2 \pm 0.1$ & $48.6 \pm 0.7$ & $40.0 \pm 0.1$ \\
$2 \mathrm{~mm}$ & $1537 \pm 13$ & 30 & $46.2 \pm 0.4$ & $58.1 \pm 0.9$ & $42.0 \pm 0.6$ \\
& & 20 & $30.7 \pm 0.3$ & $51.3 \pm 0.6$ & $41.3 \pm 0.4$ \\
& & 10 & $15.4 \pm 0.1$ & $47.8 \pm 0.8$ & $40.0 \pm 0.3$ \\
& $1366 \pm 1$ & 30 & $40.1 \pm 0.0$ & $53.1 \pm 0.8$ & $39.5 \pm 0.3$ \\
& & 20 & $27.3 \pm 0.0$ & $50.2 \pm 0.4$ & $39.3 \pm 0.4$ \\
& & 10 & $13.7 \pm 0.0$ & $46.3 \pm 1.3$ & $37.7 \pm 0.2$ \\
\hline
\end{tabular}

proximity of the TIP, coupled with an irradiance of above $1200 \mathrm{~mW} / \mathrm{cm}^{2}$, can cause high temperatures with a risk of coagulation of proteins $[12,36]$. For this reason, a risk of pulp tissue damage can occur during restorations of class $\mathrm{V}$ cavities.

The observation that the temperature distribution on the surface of the T1 was non-uniform compared to T2 is most likely due to the uneven surface topography of T1. The highest surface temperature observed was $58.1 \pm 0.9{ }^{\circ} \mathrm{C}$ for
T2 and $53.1 \pm 0.3$ for T1 (Tables 2-7). This finding is in line with previous observations $[2,24]$. Such high temperatures potentially are a risk for causing thermal damage of the soft tissue.

Within the limitations of this study, it can be concluded that increased curing time seemed to be the factor most likely to cause temperature rise. When the TIP is close to soft tissue, the risk of damage should be seriously taken into account at irradiances $>1200 \mathrm{~mW} / \mathrm{cm}^{2}$. There is also a risk of pulp damage

Table 8 Influence of curing time (time), distance, irradiance, and radiant exposure (product of irradiance and time) on temperature of the surface and pulp chamber on tooth with class I cavity (T1) and tooth with a flat dentin surface with a pulpal wall thickness of approximately $0.6 \mathrm{~mm}$ (T2) according to multiple linear regression analyses

\begin{tabular}{|c|c|c|c|c|c|}
\hline & \multirow[b]{2}{*}{ Independent variable } & \multicolumn{2}{|l|}{$\mathrm{T} 1$} & \multicolumn{2}{|l|}{$\mathrm{T} 2$} \\
\hline & & $\begin{array}{l}\text { Surface temperature } \\
\mathrm{B}(95 \% \mathrm{CI}) \\
p \text { value }\end{array}$ & Pulp chamber temperature & Surface temperature & Pulp chamber temperature \\
\hline \multirow[t]{8}{*}{ Model 1} & Time & & & & \\
\hline & $20 \mathrm{~s}(\mathrm{vs} .10 \mathrm{~s})$ & $\begin{array}{l}4.2(3.5-4.9) \\
0.000\end{array}$ & $\begin{array}{l}0.3(0.2-0.4) \\
0.000\end{array}$ & $\begin{array}{l}2.9(1.8-4.0) \\
0.000\end{array}$ & $\begin{array}{l}1.6(1.4-1.9) \\
0.000\end{array}$ \\
\hline & $30 \mathrm{~s}(\mathrm{vs} .10 \mathrm{~s})$ & $\begin{array}{l}7.2(6.5-7.8) \\
0.000\end{array}$ & $\begin{array}{l}0.9(0.8-1.0) \\
0.000\end{array}$ & $\begin{array}{l}5.2(4.0-6.3) \\
0.000\end{array}$ & $\begin{array}{l}2.6(2.3-2.8) \\
0.000\end{array}$ \\
\hline & Irradiance (per 100 units) & $\begin{array}{l}0.8(0.7-0.9) \\
0.000\end{array}$ & $\begin{array}{l}0.001(0-0.001) \\
0.000\end{array}$ & $\begin{array}{l}1.3(1.1-1.4) \\
0.000\end{array}$ & $\begin{array}{l}0.4(0.3-0.4) \\
0.000\end{array}$ \\
\hline & Distance & & & & \\
\hline & $2 \mathrm{~mm}$ (vs. $0 \mathrm{~mm}$ ) & $\begin{array}{l}-1.5(-2.2-(-0.9)) \\
0.000\end{array}$ & $\begin{array}{l}-0.05(-0.1-0.4) \\
\text { NS }\end{array}$ & $\begin{array}{l}0.4(-0.8-1.5) \\
\text { NS }\end{array}$ & $\begin{array}{l}-0.6(-0.7-(-0.3)) \\
0.000\end{array}$ \\
\hline & $4 \mathrm{~mm}$ (vs. $0 \mathrm{~mm}$ ) & $\begin{array}{l}-3.9(-4.6-(-3.3)) \\
0.000\end{array}$ & $\begin{array}{l}-0.3(-0.4-(-0.2)) \\
0.000\end{array}$ & $\begin{array}{l}-0.9(-2.0-0.3) \\
\mathrm{NS}\end{array}$ & $\begin{array}{l}-1.8(-2.0-(-1.6)) \\
0.000\end{array}$ \\
\hline & Explained variance $R^{2}$ & 0.86 & 0.84 & 0.62 & 0.85 \\
\hline \multirow[t]{5}{*}{ Model 2} & Radiant exposure (per 10 units) & $\begin{array}{l}2.9(2.7-3.2) \\
0.000\end{array}$ & $\begin{array}{l}0.3(0.3-0.4) \\
0.000\end{array}$ & $\begin{array}{l}3.0(2.5-3.4) \\
0.000\end{array}$ & $\begin{array}{l}1.2(1.1-1.3) \\
0.000\end{array}$ \\
\hline & Distance & & & & \\
\hline & $2 \mathrm{~mm}$ (vs. $0 \mathrm{~mm}$ ) & $\begin{array}{l}-1.4(-2.1-(-0.7)) \\
0.000\end{array}$ & $\begin{array}{l}-0.03(-0.1-0.05) \\
\mathrm{NS}\end{array}$ & $\begin{array}{l}0.9(-0.4-2.3) \\
\text { NS }\end{array}$ & $\begin{array}{l}-0.4(-0.7-(-0.2)) \\
0.002\end{array}$ \\
\hline & $4 \mathrm{~mm}$ (vs. $0 \mathrm{~mm}$ ) & $\begin{array}{l}-3.7(-4.4-(-3.0)) \\
0.000\end{array}$ & $\begin{array}{l}-0.3(-0.4-(-0.2)) \\
0.000\end{array}$ & $\begin{array}{l}-0.5(-1.8-0.8) \\
\text { NS }\end{array}$ & $\begin{array}{l}-1.7(-1.9-(-1.5)) \\
0.000\end{array}$ \\
\hline & Explained variance $R^{2}$ & 0.84 & 0.84 & 0.49 & 0.81 \\
\hline
\end{tabular}


when only thin dentin is left at higher irradiances. Decreased curing time may reduce the risk for soft and pulpal tissue damage but can have a negative effect on the degree of conversion. In addition, several other possibilities have been discussed to reduce overheating when using LED-LCU such as using external cooling from an airflow, polymerization at intermittent intervals, and placing gauze under the rubber dam to reduce heating the soft tissues under the rubber dam [24]. The results of the present study was limited to three LEDLCU (Bluephase style ${ }^{\circledR}$ electrically powered, Bluephase style ${ }^{\circledR}$ battery, Bluephase $\mathrm{G} 2 \AA$ ) including one LCU having two curing modes (Bluephase G2® high mode and Bluephase G2® low mode) from the same manufacturer, and whether or not other LED-LCU will behave similarly is unknown and needs to be further studied. In conclusion, the findings of this study will help clinicians to be aware of the relative importance of the factors investigated that may lead to overheating and subsequent damage to viable tissue both within the pulp chamber as well as in tissue surrounding the tooth when using LED-LCUs.

Acknowledgment The study was supported by grants from the Norwegian Directorate of Health (project number 14/1493-26).

\section{Compliance with ethical standards}

Conflict of interest The authors declare that they have no conflict of interest.

Funding The study was financially supported by the Norwegian Directorate of Health (14/1493).

Ethical approval Since the experiments involved the use of human material (i.e., extracted teeth), ethical permission was asked for from the Norwegian Regional committee for Medical and Health Research Ethics (REK). The committee concluded that such permission was not required (2015/234/REK Nord).

Informed consent For this type of study, formal consent was not required

Open Access This article is distributed under the terms of the Creative Commons Attribution 4.0 International License (http:// creativecommons.org/licenses/by/4.0/), which permits unrestricted use, distribution, and reproduction in any medium, provided you give appropriate credit to the original author(s) and the source, provide a link to the Creative Commons license, and indicate if changes were made.

\section{References}

1. Bouillaguet $\mathrm{S}$, Caillot $\mathrm{G}$, Forchelet J, Cattani-Lorente $\mathrm{M}$, Wataha JC (2005) Thermal risks from LED- and high-intensity QTH-curing units during polymerization of dental resins. J Biomed Mater Res B Appl Biomater 72(2):260-267
2. Aksakalli S, Demir A, Selek M, Tasdemir S (2014) Temperature increase during orthodontic bonding with different curing units using an infrared camera. Acta Odontol Scand 72(1):36-41. doi:10.3109/00016357.2013.794954

3. Nomoto R, McCabe JF, Hirano S (2004) Comparison of halogen, plasma and LED curing units. Oper Dent 29(3):287-294

4. "LED", in The American Heritage Science Dictionary (2005) Houghton Mifflin Company

5. Park SH, Roulet JF, Heintze SD (2010) Parameters influencing increase in pulp chamber temperature with light-curing devices: curing lights and pulpal flow rates. Oper Dent 35(3):353-361. doi:10.2341/09-234-L

6. Atai M, Motevasselian F (2009) Temperature rise and degree of photopolymerization conversion of nanocomposites and conventional dental composites. Clin Oral Investig 13(3):309-316. doi:10.1007/s00784-008-0236-2

7. Eldeniz AU, Usumez A, Usumez S, Ozturk N (2005) Pulpal temperature rise during light-activated bleaching. J Biomed Mater Res B Appl Biomater 72(2):254-259

8. Durey K, Santini A, Miletic V (2008) Pulp chamber temperature rise during curing of resin-based composites with different light-curing units. Prim Dent Care 15(1):33-38. doi:10.1308/135576108783328409

9. Shortall AC, Harrington E (1998) Temperature rise during polymerization of light-activated resin composites. J Oral Rehabil 25(12): 908-913

10. Malkoc S, Uysal T, Usumez S, Isman E, Baysal A (2010) In-vitro assessment of temperature rise in the pulp during orthodontic bonding. Am J Orthod Dentofac Orthop 137(3):379-383. doi:10.1016/j. ajodo.2008.02.028

11. Hannig M, Bott B (1999) In-vitro pulp chamber temperature rise during composite resin polymerization with various light-curing sources. Dent Mater 15(4):275-281

12. Zach L, Cohen G (1965) Pulp response to externally applied heat. Oral Surg Oral Med Oral Pathol 19:515-530

13. Spranley TJ, Winkler M, Dagate J, Oncale D, Strother E (2012) Curing light burns. Gen Dent 60(4):e210-e214

14. Knezevic A, Tarle Z, Meniga A, Sutalo J, Pichler G (2005) Influence of light intensity from different curing units upon composite temperature rise. J Oral Rehabil 32(5):362-367

15. Savas S, Botsali M, Kucukyilmaz E, Sari T (2014) Evaluation of temperature changes in the pulp chamber during polymerization of light-cured pulp-capping materials by using a VALO LED light curing unit at different curing distances. Dent Mater J 33(6):764 769

16. Alnazzawi A, Watts DC (2012) Simultaneous determination of polymerization shrinkage, exotherm and thermal expansion coefficient for dental resin-composites. Dent Mater 28(12):1240-1249. doi:10.1016/j.dental.2012.09.004

17. Guiraldo RD, Consani S, Sinhoreti MA, Correr-Sobrinho L, Schneider LF (2009) Thermal variations in the pulp chamber associated with composite insertion techniques and light-curing methods. J Contemp Dent Pract 10(1):17-24

18. Guiraldo RD, Consani S, De Souza AS, Consani RL, Sinhoreti MA, Correr-Sobrinho L (2009) Influence of light energy density on heat generation during photoactivation of dental composites with different dentin and composite thickness. J Appl Oral Sci 17(4):289-293

19. Baroudi K, Silikas N, Watts DC (2009) In vitro pulp chamber temperature rise from irradiation and exotherm of flowable composites. Int J Paediatr Dent 19(1):48-54. doi:10.1111/j.1365-263 X.2007.00899.x

20. Gomes M, DeVito-Moraes A, Francci C, Moraes R, Pereira T, Froes-Salgado N, Yamazaki L, Silva L, Zezell D (2013) Temperature increase at the light guide tip of 15 contemporary LED units and thermal variation at the pulpal floor of cavities: an 
infrared thermographic analysis. Oper Dent 38(3):324-333. doi:10.2341/12-060-L

21. Leprince J, Devaux J, Mullier T, Vreven J, Leloup G (2010) Pulpaltemperature rise and polymerization efficiency of LED curing lights. Oper Dent 35(2):220-230. doi:10.2341/09-203-L

22. Santini A, Watterson C, Miletic V (2008) Temperature rise within the pulp chamber during composite resin polymerisation using three different light sources. Open Dent J 2:137-141. doi:10.2174 /1874210600802010137

23. Price RB, Ferracane JL, Shortall AC (2015) Light-curing units: a review of what we need to know. J Dent Res 94(9):1179-1186. doi:10.1177/0022034515594786

24. Price RB, Shortall AC, Palin WM (2014) Contemporary issues in light curing. Oper Dent 39(1):4-14. doi:10.2341/13-067-LIT

25. AlShaafi MM, Harlow JE, Price HL, Rueggeberg FA, Labrie D, AlQahtani MQ, Price RB (2015) Emission characteristics and effect of battery drain in "budget" curing lights. Oper Dent In-Press

26. Haenel T, Hausnerova B, Steinhaus J, Price RB, Sullivan B, Moeginger B (2015) Effect of the irradiance distribution from light curing units on the local micro-hardness of the surface of dental resins. Dent Mater 31(2):93-104. doi:10.1016/j.dental.2014.11.003

27. Price RB, Labrie D, Whalen JM, Felix CM (2011) Effect of distance on irradiance and beam homogeneity from 4 light-emitting diode curing units. J Can Dent Assoc 77:b9

28. Price RB, Dérand T, Sedarous M, Andreou P, Loney RW (2000) Effect of distance on the power density from two light guides. $\mathrm{J}$ Esthet Dent 12(6):320-327
29. Corciolani G, Vichi A, Davidson CL, Ferrari M (2008) The influence of tip geometry and distance on light-curing efficacy. Oper Dent 33(3):325-331. doi:10.2341/07-94

30. Shortall A, El-Mahy W, Stewardson D, Addison O, Palin W (2013) Initial fracture resistance and curing temperature rise of ten contemporary resin-based composites with increasing radiant exposure. $\mathrm{J}$ Dent 41(5):455-463. doi:10.1016/j.jdent.2013.02.002

31. Selig D, Haenel T, Hausnerova B, Moeginger B, Labrie D, Sullivan B, Price RB (2015) Examining exposure reciprocity in a resin based composite using high irradiance levels and real-time degree of conversion values. Dent Mater 31(5):583-593. doi:10.1016/j.dental.2015.02.010

32. Asmussen E, Peutzfeldt A (2003) Light-emitting diode curing: influence on selected properties of resin composites. Quintessence Int 34(1):71-75

33. Price RB, Labrie D, Rueggeberg FA, Sullivan B, Kostylev I, Fahey J (2014) Correlation between the beam profile from a curing light and the microhardness of four resins. Dent Mater 30(12):13451357

34. Oberholzer TG, Makofane ME, du Preez IC, George R (2012) Modern high powered led curing lights and their effect on pulp chamber temperature of bulk and incrementally cured composite resin. Eur J Prosthodont Restor Dent 20(2):50-55

35. Yazici AR, Müftü A, Kugel G, Perry RD (2006) Comparison of temperature changes in the pulp chamber induced by various light curing units, in vitro. Oper Dent 31(2):261-265

36. Baldissara P, Catapano S, Scotti R (1997) Clinical and histological evaluation of thermal injury thresholds in human teeth: a preliminary study. J Oral Rehabil 24(11):791-801 